\title{
TOWARDS A PROGRESSIVE AGENDA FOR THE EU?*
}

\section{Suna Gülfer IHLAMUR-ÖNER **}

\section{Abstract}

The European Union is facing serious challenges that test its solidarity and unity in the age of insecurity and anxiety. The Eurozone debt crisis, the socalled "migration crisis" and recently the health crisis and economic downturn instigated by COVID-19 have posed the most formidable challenges to the European project and the EU member states. Given a series of crises and challenging questions facing the EU in less than a decade, it seems timely to discuss and evaluate a progressive vision for the future of the EU. This paper argues that the pandemic has shown the importance and urgency of the core progressive objectives and opened a window of opportunity for progressive politics to advance a new agenda for the EU based on social justice, inclusiveness, equality, and pluralism. This new agenda has the potential to rejuvenate European integration while also allowing the progressives to confront the rise of the radical right in Europe. The paper particularly seeks to address to what extent progressive politics could shift the political agenda away from migration and security issues, create a new movement based on new thinking and a narrative in the face of COVID-19 and take an active part in the transformation of European politics and the EU.

Keywords: EU, progressive politics, social Europe, international migration, neoliberal globalization, COVID-19.

\section{AB İÇİN ILERLEMECI BİR AJANDAYA DOĞRU MU? \\ $\ddot{O}_{z}$}

Avrupa Birliği, güvensizlik ve endişe çağında dayanışmasını ve birliğini sınayan ciddi zorluklarla karşı karşıyadır. Euro bölgesi borç krizi, sözde "göç krizi" ve son zamanlarda COVID-19'un neden olduğu sağllk krizi ve ekonomik sorunlar, Avrupa projesi ve AB üye ülkeleri için önemli zorluklar oluşturmaktadır. AB'nin on yıldan kısa bir süre içinde karşı karşıya kaldı̆̆ı bir

* An earlier version of this article has been presented at the Marmara Conference on European Studies 2020 (MCES-2020), İstanbul, 7-8 February, 2020.

** Assoc. Prof., Marmara University, Department of Political Science and International Relations, e-mail: gihlamur@marmara.edu.tr. 
dizi kriz ve zorlu sorular göz önüne alındığında, AB'nin geleceği için ilerici bir vizyonu tartışmak ve değerlendirmek için en doğru zamanda bulunmaktayı. Bu makale, pandeminin ilerici siyasetin temel hedeflerinin önem ve aciliyetini gösterdiğini ve ilerici siyasetin AB için sosyal adalet, kapsayıcılık, eşitlik ve çoğulculuğa dayanan yeni bir gündem geliştirmesi için bir firsat penceresi açtı̆̆ını ileri sürmektedir. Yeni ilerici gündem, Avrupa entegrasyonunu yeniden canlandırma potansiyelini taşırken, ayn zamanda ilerici siyasetin Avrupa'da radikal sağın yükselişiyle yüzleşmesine olanak tanıyacaktır. Makale ilerici siyasetin siyasi gündemi göç ve güvenlik sorunlarından uzaklaştırabilmesinin, COVID-19 karşısında yeni düşünceye dayall yeni bir hareket ve bir anlatı yaratabilmesinin ve Avrupa siyaseti ve AB'nin dönüşümünde etkin rol alabilmesinin imkanlarını ele almaktadır.

Anahtar Kelimeler: AB, ilerlemeci siyaset, sosyal Avrupa, uluslararası göç, neoliberal küreselleşme, COVID-19.

\section{Introduction}

Neoliberal capitalism has unleashed drastic changes in the world since the late 1970s, which have deepened socio-economic inequalities. European integration that took a neoliberal turn with the Maastricht Treaty proceeds with fragmenting labour processes, dismantling Social Europe, and paving the way for a series of crises the European Union (EU) is facing that test its solidarity and unity in the age of insecurity and anxiety. While growing inequalities and processes of precarization under neoliberal globalization render a growing number of people within the boundaries of the EU more vulnerable, the Eurozone debt crisis and the so-called "migration crisis" have posed the most formidable challenges to the European project and the EU member states. While these crises weakened European solidarity, the radical right capitalized on voters' frustrations as well as fears linked to migration and asylum, which paved the way for the populist right's political and electoral success. Recently, the radical right has taken its anti-EU challenge from the national to the EU level. However, the most formidable challenge to the EU came with the outbreak of COVID-19, which soon turned into a pandemic and changed our lives for the better and worse.

European integration today is at a crossroads today, as its strength and solidarity have been tested with the challenges of growing migration and pandemic-triggered health and economic crises. Given a series of crises and challenging questions facing the EU in less than a decade, which the EU seems ill-equipped to deal with, it is time to discuss and evaluate a progressive vision for the future of the EU. This paper argues that the pandemic has shown the importance and urgency of the core progressive objectives and opened a window of opportunity for progressive politics to advance a new agenda for the 
EU based on social justice, inclusiveness, equality, and pluralism. This new agenda has the potential to rejuvenate European integration while also allowing the progressives to confront the rise of the radical right in Europe. The paper particularly seeks to address to what extent progressive politics could shift the political agenda away from migration and security issues and formulate a rights-based approach to migration and asylum, a key question that is haunting the democracies in Europe.

Before setting out to assess possible responses by the progressives in the post-COVID-19 era, this paper takes a new look at the failed attempts of progressives to build Social Europe as European integration progressed along neoliberal lines. The paper then seeks to evaluate the inability of progressive politics to challenge neoliberalism during and after the 2008 eurozone crisis, when the radical right parties were shaping national and European politics by presenting immigration as a threat to European societies. After an evaluation of the impact of the pandemic on politics, democracy and populism and the EU's response to it, the paper concludes by discussing the possible responses by progressive politics to the challenging questions that the EU faces to become a relevant and influential actor in European politics in the post-coronavirus world.

\section{Why Progressive Politics Matter?}

Progressivism eludes neat definitions. Progressive is rather an "umbrella term" referring to a movement composed of alliances among a diverse set of actors. Even within the Left, there is disagreement over what it entails (Robinson, 2017: 2-3). Therefore, it will not be wrong to argue that it is an ambiguous term.

The concept of progressive politics is as old as social democracy itself, explicitly stating that the labour movement is always up-to-date, capable of adapting to change and innovating itself (Skrzypek, 2015). It is often used to refer to the left-wing way of looking at the world, even if some groups or movements define themselves as progressive and challenge its association with the Left (Wheeler, 2010). Within the British context, the term was originally used for the left-liberal progressive movement in the late $19^{\text {th }}$ and early $20^{\text {th }}$ centuries. In today's Britain the position of the progressives could be defined as "left-of-center" (Robinson, 2017: 2). Within the American context, progressivism refers to a reform movement centering on social justice that emerged in the late $19^{\text {th }}$ century and was influential until the 1920 s (Nugent, 2010: 2). The progressives seeking to protect the "common good" believed that "something needs to be done" and demanded from local, state, or federal governments to introduce economic regulations for the resolution of social problems (Nugent, 2010: 3, 5). The progressive stance emphasizes the role of 
government in the economy in making regulations and making economic actors respect the rules and regulations for the protection of the public good (Sirota, 2011).

Seeking to define progressivism with what it is not, one may argue that being a progressive means you are not a neoliberal that valorizes the market. You are not a communitarian either, as you prioritize individual autonomy and freedom over the community. A progressive could be defined as someone hopeful about the future (Rowson, 2015). Those who define themselves as "progressives" are in favour of reform for the society to progress towards more freedom (Wheeler, 2010). They are socially liberal and fight for more rights for the people while believing in progress through technological advancement, modernization, and redistribution of wealth. In this paper, I am using progressive politics in this sense and progressive politics, social democracy or the Left somewhat interchangeably.

The term progressivism has been intentionally chosen as it is "open to evolution, appropriation and redefinition" (Robinson, 2017: 16). Progressive politics is a future-oriented reform movement seeking to transcend the problems of the past and present based on a set of principles (Robinson, 2017: 14). Therefore, the paper seeks to emphasize the potential of the progressive politics to form a movement composed of a broad coalition that could stand the challenge of radical right populism and neoliberal ideology, revive Social Europe and recast European integration.

\section{Social Europe vs. Market Europe}

The labour movement grew in power and influence in liberal democracies through the development of the welfare state. The welfare state systems simultaneously have served to demobilize the working classes to prevent their challenge to the capitalist system (Ryner, 2018: 253). Within this context, the Left used to have an agenda-setting power, especially in terms of making the governments commit themselves to combat unemployment, but it has lost it in the years after the 1970s (Ryner, 2018: 200). Progressive politics evolved from the mid-1970s onwards within the context of neoliberal globalization (Coates, 2018: 3100). This is the period when the decline of social democratic parties started in Europe (Bailey, 2018: 5274), as the transition from Fordism to postFordism, post-industrial society, and service-based economy led to a decline in industries or working-class jobs and weakening of working-class solidarities.

From the 1960s onwards we also see the emergence of new social movements in the West, which superseded the right-left cleavage. Rather than the "old" labour movement, the "new social movements" now constituted the "progressive actors". The decline of labour in the shift from industrial to postindustrial society coincided with also a shift from material to post-material 
values. The vacuum left by the labour movement was filled by civil society and new social movements taking cultural questions as their focus (Mathers, 2007: 9-10). Within the context of neoliberal restructuring, a shift has occurred from class politics towards identity politics that grew out of new social movements. It was based on the quest for recognition of particular group identities, which further weakened the labour movement. Rather than leading the opposition against growing unemployment and poverty due to economic restructuring, the organized labour retreated and sought to accommodate to the new politics (Mathers, 2007: 30-31).

Since its inception, negative integration (mainly market integration through removing tariff and non-tariff barriers to trade and preventing distortions of competition) has been the main form of European integration, facilitated by supranational European law. Positive integration, which meant formulating common policies to set the framework and conditions within which the markets will operate, was much more difficult to achieve, as it required the consensus of all the member states (Scharpf, 1995: 7). While harmonization was achieved in product-related regulations, positive integration was hard to achieve in environmental and welfare regulations (Scharpf, 1995: 20). The European Social Dimension, which depended on the construction of new policies, structures and institutions for social protection by the member states, was overshadowed by negative integration, as it gained pace with the Single European Act of 1987 (Hacker, 2014: 3-4; Schierup, Hansen and Castles, 2006: 59). Therefore, the social dimension was subordinated to the single market initiative.

The goal of creating an internal market by the end of 1992 led the labour movement to mobilize against the single market initiative in order to prevent it from shifting the balance further against labour and Social Europe and to add a social dimension to the single European market (Silvia, 1991: 631). This move was endorsed by Jacques Delors, the $8^{\text {th }}$ President of the European Commission between 1985-1995, who sought to develop a legally binding "Social Charter". However, this attempt failed to due to the British opposition, which saw the Charter as an impediment in the way of job creation (Silvia, 1991: 635) and the charter was added solely as an appendix to the Treaty of Maastricht (Mathers, 2007: 107), while 1985 White Paper on the internal market, had hundreds of binding directives (Silvia, 1991: 639). The failure of Delors' Social Europe Plan also meant the failure of the efforts to formulate a strong supranational welfare policy in the EU.

European integration took a neoliberal turn from the early 1990s onwards following the signing of the Maastricht Treaty. The European Commission's White Paper on "Growth, Competitiveness, Employment" in 1993 called for "a flexible labour market, a set of 'more enterprise friendly' regulations, reduced 
labour costs and unemployment benefits, lower taxes, cutbacks in welfare systems and overall public expenditures, and increased privatization". Within the post-Maastricht EU, concerns about inequality were pushed to the background, while the "core concern now became to reconcile 'social cohesion' with "economic efficiency". What we see in the post-Maastricht EU could be defined as a "turn away from redistribution" (Schierup, Hansen and Castles, 2006: 55). Social participation came to mean mainly "market activity". Therefore, it will not be wrong to argue that "Market Europe" triumphed over "Social Europe" (Schierup, Hansen and Castles, 2006: 55-56). Social democratic parties that came to power in the late 1990s also played a significant role in this, as they embraced neoliberal policies rather than challenging them.

Full employment demands by the leftwing political parties or trade unions were seen as "defensive" and even "reactionary" (Mathers, 2007: 13) or resistance against the drastic changes in the economy or defending the welfare state was seen as the incapability of the labour movement to adapt to "new politics". As the Keynesian welfare system was challenged by neoliberal ideology and was in crisis, the stability introduced by Keynesian economics was also gone. Trade unions saw economic restructuring as a threat rather than an opportunity to restructure themselves (Mathers, 2007: 29-30).

The neoliberal turn of the EU project had significant consequences for the working classes. Growing unemployment, welfare retrenchment, and fall in wages were important consequences of the European monetary system. Austerity, privatization and structural reforms introduced through structural adjustment programs led to the commodification of labour. In the 1990s, a new wave of protests and movements emerged in Europe against the neoliberal economic reforms and austerity measures resulting from convergence criteria such as cuts in government spending, which had drastic consequences for the working class (Mathers, 2007: 31). As the EU was heading towards the European Monetary Union (EMU) European Marches to Amsterdam emerged as a response to growing unemployment and the inability to meet the basic needs (Mathers, 2007: 87).

Growing discontent in Europe carried social democrats or socialists to power in the 1990s. However, when in power these parties pursued marketbased policies to address social and economic problems. The image of social democracy was tarnished due to its capitulation to neoliberalism (Coates, 2018: 3153). European social democracies actively promoted neoliberal reforms and took part in the reproduction of capitalist social relations in Europe (Ryner, 2018: 2196). They have abandoned their core commitments. Even Sweden abandoned its commitment to full employment (Ryner, 2018: 2231). President Mitterrand in France took a "u-turn" in 1983, as the government began cuts in spending and took a step back from its "worker-friendly policies" (Bailey, 
2018: 5293). The trade unions did not compromise to neoliberal ideology but retreated as their power and influence decreased (Ryner, 2018: 2269).

The social democratic parties moved towards the center by embracing neoliberal policies. The then-leader of the Social Democratic Party of Germany (SPD), Gerhard Schröder claimed that the party represents "the new center". As social democratic parties moved closer to center, radical left parties filled in the void left by social democracy (Bailey, 2018: 5318). ${ }^{1}$ Successive defeats of the Left in the UK led Giddens to formulate his "Third Way", which was beyond left and right and which had a significant impact on the social democratic parties that have accommodated to the process of neoliberalization (Mathers, 2007: 21-22). The Third Way was presented as an alternative between Keynesianism and neoliberalism and updating or modernization of the social democratic tradition (Coates, 2018: 3119). As Labour Party embraced the Third Way, it set new electoral targets and abandoned the north and the Midlands, which was its main constituency. Throughout its rule from 1997 to 2010, it turned its main attention to London's financial services (Niven, 2019). Following Blair, social democratic leaders such as Schröder in Germany and Prodi in Italy made their own "Third Way" (Coates, 2018: 3123). As social democracy opted for the Third Way, there occurred a shift from "a redistributionist to an integrationist discourse in the EU", which was also embraced by the European Commission.

Social democrats claimed to uphold the "European Social Model" while undermining the welfare state by implementing neoliberal policies (Schierup, Hansen, and Castles, 2006: 56). The social democrats sought to counter Thatcher and Thatcherism through European integration (Bailey, 2018: 5302). It was "safe" to push for Social Europe within the EU context, as it allowed the Left to blame the others when the goals linked with Social Europe could not be achieved (Bailey, 2018: 5306). Within this context, the EU continued to introduce plans to combat social exclusion. In 2000 at the Nice Council, a new European Social Policy Agenda (SPA) was adopted to revive the European social model. It was also a component of the Lisbon Strategy. However, these plans were formulated from a neoliberal logic and concerns about “"employability', 'flexibility', 'social cohesion', and 'moral obligation"”

\footnotetext{
${ }^{1}$ With the end of the Cold War in a neoliberal globalization context, the communist parties went through a process of marginalization, which also led to their transformation (Bailey, 2018: 5308). For instance, the Italian Communist Party was transformed along social democratic lines and was renamed as the Party of the Democratic Left (PDS), then the Democrats of the Left (DS). Then the party was further transformed as it united with several Christian Democratic parties to become the centrist Democratic Party (PD), while Rifondazione Comunista continued to stick to its Eurocommunist ideals, but turned into a small party (Bailey, 2018: 5309).
} 
dominated over concerns about "social inequality" and "social rights". Flexibility subordinated the social policy to economic policy, which meant the transformation of welfare into workfare as well as welfare retrenchment and dismantling of social citizenship (Schierup, Hansen and Castles, 2006: 60-61).

As European integration's social dimension came under pressure of marketbased reforms, the basis of the legitimacy of the European project started to erode. The Treaty of Amsterdam introduced a high level of employment and social protection goals as well as competition (Mathers, 2007: 112-113). However, the policies that the EU promoted intending to "modernize" the European Social Model has moved European integration from the ideal of Social Europe, which is fairer, equal, and democratic Europe (Mathers, 2007: 181). Neoliberal Europe promoted by the EU institutions transformed European integration into "Unsocial Europe" (Mathers, 2007: 105) and the vision of Social Europe is undermined.

The first major "legitimacy crisis" of the European project came with the French and Dutch rejection of the Constitution (van Apeldoorn, 2009: 21) and the Irish rejection of the Lisbon reform treaty in June 2008 that was prepared to replace the Constitution. One of the main reasons behind the "no" vote was the EU's disregard for the social consequences of the Constitution. (van Apeldoorn, 2009: 39-40). 2008 eurozone crisis, which has undone the partial achievements of the Lisbon strategy, ${ }^{2}$ the so-called 2015 "migration crisis" and finally the spread of COVID-19 in Europe constituted major blows to European integration and solidarity among member states.

\section{The Crisis of Neoliberalism and Social Democracy}

2008 eurozone crisis started with the collapse of Iceland's banking system, then spread primarily to Ireland, Greece, Spain, Portugal, and Italy in 2009. The Troika composed of the European Commission, the European Central Bank (ECB) and International Monetary Fund (IMF) made an agreement to bail out Greece and a few other member states through Memoranda of Understanding requiring them to implement severe austerity measures, which could be summarized as raising taxes and cutting spending (Robbins, 2015: 180).

2008 Eurozone crisis was the crisis of neoliberal economic reforms. Neoliberal logic shapes and informs the European integration since the 1980s but particularly after the signing of the Maastricht Treaty. However,

\footnotetext{
2 The Lisbon Strategy, launched in 2000, was devised to make EU economies "dynamic" and "knowledge-based" in the face of growing global competition to boost economic growth by 2010. It was relaunched in 2005 focused mainly on jobs and economic growth, assuming that economic growth through increased competition will automatically benefit all. Even though the EU created 18 million new jobs, it failed to close the productivity gap with the leading economies and reduce poverty or working poverty (European Commission, 2010).
} 
neoliberalism continued to dominate policy-making and enforcement in the EU even after 2008. To deal with the crisis of neoliberalism, neoliberal crisis management was put into practice. Basically, through bail-out programs austerity measures were introduced. The Memoranda of Understanding that the Troika made with the member states such as Greece or Spain was no different from the IMF's structural adjustment programs (Ryner, 2018: 195). Key elements of the neoliberal version of crisis management could be summarized as restructuring of the banking sector, the labour and pensions reforms, underinvestment in the real economy, education, innovation, and research, improving the competitiveness of the member state's economy, restructuring of the labour market, facilitating "hire and fire", greater flexibility in collective bargaining at the firm level (Mendizabal, 2014: 15). These neoliberal austerity measures introduced to address recession did not address the structural weaknesses, while restoring competitiveness made the markets more flexible for the firms but less secure for the workers, weakening the bargaining power of the workers.

The austerity measures that exacerbated the recession rather than alleviating it allowed neoliberalism to reinvent itself and extended its life, while many claimed that it is in crisis (Worth, 2018: 5095). Even if the neoliberal economic reforms have failed to bring about economic growth, the impact of neoliberal ideas has been very profound over the policy-makers and voters (Coates, 2018: 3152-3153). Moreover, neoliberalism gives rise to movements that oppose it but it also capable of fragmenting these movements. Therefore, the 2008 crisis did not "discredit" the existing neoliberal order, much to the chagrin of progressives, it strengthened it. Colin Crouch labeled this phenomenon as the "Strange Non-Death of Neoliberalism" (Skrzypek, 2015: 11). The Eurozone crisis did not benefit the Left. PASOK and PSOE were punished by the electorate and voted out of office in the elections after agreeing to bail-out plans of the Troika.

In the post-2008 context, we have witnessed the "inability" of progressive politics to "challenge neoliberalism despite it being in crisis" (Bailey, 2018: 5335). From the 1980 s to 2008 , we have witnessed the transformation of social democratic parties capitulating to neoliberalism and seeking to convince their electorate that giving into neoliberalism is necessary for economic growth. Now it is hard for the leftwing parties to declare that they were wrong and this is one of the main reasons why people have lost faith in progressive politics. Moreover, the Left is suffering from a lack of a "clear and consistent approach to the global economic crisis" and a "failure to develop a coherent alternative" (Bailey, 2018: 5333-5334). 


\section{Growing Migration, Resurgence of the Radical Right, and Decline of the Left}

In many two-party systems based on the right-left cleavage, the Left was the main rival of the conservatives. Now it is challenged with the political and electoral success of the radical right parties in Europe. In different political contexts in Europe, the radical right parties emerged as significant rivals and expanded at the expense of the Left. The social democratic parties are shrinking and seek to "keep their middle-class cosmopolitan voters as well as their traditional working-class base" (Boros, 2016). While the populist right parties have become the main opposition parties or coalition partners in some liberal democracies, the mainstream parties embraced the populist discourses and policies to preserve their constituencies. Therefore, populism started shaping the policies and politics of the EU member states.

After the end of WWII, the interwar fascism was defeated, the extreme right parties lost their legitimacy and were pushed to the margins of the postwar political system. Liberal democracies had a stronger determination to avoid a repetition of the breakdown of democracy and the violation of human rights (Kallis, 2014: 9). Until the 1980s these parties were marginal and did not have any electoral success. The late 1980s and 1990s witnessed the emergence of the "new radical right" as a political platform, relaunching fundamental themes, which are nationalism, opposition to liberal values and communism, attack on immigration, intolerance vis-à-vis minority groups. Neoliberal globalization and post-Maastricht widening and deepening of European integration weakened the sense of security, solidarity, and belonging in Europe which were closely associated with the nation-states and national identities (Berezin, 2011: 6). Heightened insecurity and anxiety about identity and welfare, new risks, and insecurities in the post-Cold War era coupled with a backlash against multiculturalism and growing Islamophobia provided a fertile breeding ground for the radical right parties and movements in Europe. As immigration increasingly became the central aspect of the mainstream political discourse and was increasingly securitized and criminalized from the 1990s onwards, we have seen growing electoral and political success of the populist right parties.

As Mudde's "pathological normalcy" thesis suggests, populist radical right attitudes and ideas are not marginal in Europe, but fairly widespread. What we witness could be defined as the radicalization of mainstream views (Mudde, 2007: 296-297). Radical right parties' political and socio-cultural influence lies in their political agenda-setting "success" and not focusing primarily on socioeconomic issues such as unemployment, but rather on socio-cultural issues, mainly immigration. They pursue the strategy of increasing the saliency of "their" issues. The populist right succeeded in "redefining politics around issues of nation, culture, identity", which are security and immigration (Bloomfield, 
2020: 90), and presenting itself as the "patriotic saviours of the nation" against global forces threatening the sovereignty of the nation-state.

The rise of the radical right is premised on its ability to present immigration as a threat to European societies. Immigration is the most challenging issue for the progressives, as on the one hand, they have to defend the right to freedom of movement while taking the citizens' concerns about security and public order into consideration on the other (Skrzypek, 2015: 16). The populists blame the Left for helping bring the immigrants in the country while disregarding what the ordinary citizens need or demand. As the pro-migration stance started eroding the social democratic parties' voter base, many leftwing parties argued for accepting refugees while, at the same time, calling for the adoption of border enforcement measures to protect the security, national identity, and labour market. However, this strategy did not succeed so far, as the voters are more prone to opt for the radical right parties that present themselves as the defenders of national identity and emphasize social order and security (Boros, 2016).

Social democratic parties have a complex relationship with immigration and multiculturalism. Throughout the 1980s and 1990s, these parties supported immigration and multiculturalism. However, they also supported restrictions on both labour and forced migration. The Labour Party pursued policies to expand labour migration but adopted a more restrictive stance towards the asylum. In 2007 Gordon Brown made a "British jobs for British workers" speech, similar to the slogan of National Front in the 1970s. Tony Blair and Matteo Renzi both argued that migration should be controlled or limited. Following the so-called "migration crisis" in 2015, the social democratic parties started defending a more restrictive stance towards migration. For instance, the leader of Belgium's Socialist Party stated that "migration to Europe must decrease", while the leader of SPD argued that Germany cannot accept all the asylum-seekers arriving in Germany. The Danish Social Democrats defined immigration as a challenge to the Danish welfare state (Mudde, 2019). Within the Labour Party, there is even a group called Blue Labour, backing anti-immigrant and pro-family policies (Chaplain, 2019). ${ }^{3}$

${ }^{3}$ Blue Labour was established in 2010 by pro-Brexit Maurice Glasman, who claims to represent the core values of the party pre-1945. It is a group that defends Christian values and patriotism. The group argues that the Labour Party should be "economically radical and culturally conservative" (Chaplain, 2019). Glasman accused the New Labour of disregarding the traditional working class and their values and concerns while adopting what he calls the "trendy cosmopolitanism" shaped by feminism and multiculturalism (Bloomfield, 2020: 90). The working class that the Blue Labour is referring to is "white" disregarding the majority of the current working class (Bloomfield, 2020: 93). 
However, immigration is not the reason why the Left is losing votes or elections as some leftwing leaders claim or imply (Mudde, 2019). When the Left or mainstream parties prioritize the immigration issue, they play into the hands of the populist right as it is "the issue" that radical right capitalizes on. As Boros (2016) argues: "The more the political agenda is dominated by the question of refugees, the more populist parties will gain support, and the more countries they will rise to power in. In the end, despite the Left's best efforts, it is the refugees who will suffer the most from this process."

Social democracy is not losing ground because working-class people are voting for the populist right either (Mudde, 2019). The voter share of social democratic parties was above $30 \%$ in the 1950 s and started to decline in the 1980 s. With the electoral success of social democratic parties in countries such as Germany, the UK, and Italy, support for social democracy increased in the 1990s, however, it started to decrease throughout the 2000s (Benedetto, Hix, and Mastrorocco, 2019: 4-5). In 2017 it fell below 20\%, which is the lowest level of electoral support for social democratic parties in Europe since 1918 (Benedetto, Hix, and Mastrorocco, 2019: 9). The main motivation of many leftwing parties is now not winning the elections, but not losing it (Skrzypek, 2015: 14). The electoral success of the populist left, Podemos in Spain and Syriza in Greece, in the aftermath of the 2008 eurozone crisis was shortlived. It was not a new "progressive dawn" as the Left has hoped it to be. The Syriza experiment failed, while Podemos lost vigour.

To better account for the decline in the voters' support, the constituency of the labour parties has to be analyzed. While the working class is the main constituency of the Left, not all the members of the working class are voting for the Left (Mudde, 2019). The transformation of the working class is another important factor to be taken into consideration. One of the reasons behind the Labour Party's defeat and Conservative Party's victory in the general elections in the UK in December 2019 is the Labour's loss of voters in the deindustrialized parts of the English north and Midlands. The destruction of the mines, factories, and shipyards led to the dissolution of class solidarities and industrial communities (Niven, 2019). The industrial workforce in postindustrial societies has shrunk. Based on the eight waves of European Social Survey in 14 European countries between 2002-2016 Benedetto, Hix and Mastrorocco (2019: 18-19) argue that the industrial workforce (in mining or extraction, manufacturing, or construction) declined by $20 \%$, and this was also reflected in the decline of the votes of social democratic parties. Moreover, class structures became highly complicated and fragmented. Today, the "white" working class represents a shrinking portion of the working class (Bloomfield, 2020: 93), while a growing number of women and workers of immigrant descent join the workforce. Moreover, the precarization of labour, which is a 
consequence of Europeanization and "economic integration through social fragmentation" that is deliberately disassociated from socially integrative standards despite a constant reference to Social Europe (Hürtgen, 2020: 14), is weakening the working-class solidarities (Hürtgen, 2020: 11). European integration is based on and proceeds through fragmenting the labour processes and dividing the workforce into competitive coalitions (Hürtgen, 2020: 5, 13) and even the "protected" workforce becomes subject to wage cuts, flexibilization and growing uncertainty about work (Hürtgen, 2020: 4). Therefore, the Left has to develop strategies to oppose the processes of precarization that weaken the workforce and incorporate the precariat into the broader movement for social justice to be relevant.

\section{COVID-19 and the Future of the EU}

The world has heard about coronavirus outbreak in the Chinese city of Wuhan at Hubei province in December 2019. As it was soon renamed as COVID-19, it started spreading to other Asian countries and then to Italy in Europe. As the World Health Organization declared COVID-19 a pandemic on 12 March 2020, the epicenter of the disease was Europe (World Health Organization, 2020), which soon shifted to the US with the highest number of confirmed coronavirus cases and a very steep rise in death rates (Levenson, 2020).

The pandemic has triggered a health crisis and put the health systems under enormous strain. Within the European context, this crisis has shown the implications of neoliberal economic reforms on health services. COVID-19 has shown how the privatization of health and the dismantlement of the welfare state could have a very high human cost. The crisis has proved that access to healthcare is a human right and should be the main priority. Public provision of health services is an issue that the Left has always emphasized and from now on should further emphasize.

The health crisis did also have significant economic repercussions. As the IMF Managing Director Kristalina Georgievai states the economic impact of the pandemic is much more severe than the global financial crisis and recovery seems possible only from 2021 onwards (IMF, 2020). Due to the economic downturn, the world's biggest economies are shrinking. As reported by the US Bureau of Labor Statistics (2020), in the US, unemployment skyrocketed to 14.7\% in April 2020 from 4,4 in March 2020. As businesses reopened the unemployment rate fell to $10.2 \%$ in July 2020 , however, it is still very high, and economic recovery is slow (US Bureau of Labor Statistics, 2020). As a consequence of the COVID-19, the Eurozone economy experienced the sharpest decline on record since 1995 . While it shrank by $12.1 \%$ in the second quarter of 2020, according to the Eurostat figures the Gross Domestic Product 
for the EU is estimated to have fallen by $11.9 \%$ (Tidey, 2020). The economic impact of lockdowns in Europe will be longlasting and maybe far more destructive then we can imagine. Certain jobs, particularly in the services sector in the US and Europe, are not coming back. The damage control efforts of the US administration or European states may provide some relief but may not be enough in a world in which the "radical uncertainty" becomes the new normal (Tooze, 2020).

The health and economic crises have global implications but do not affect everyone in the same way. They hit the most vulnerable segments of the society in the Global North, while the Global South has limited means to deal with the crisis. In Europe, the impact of the coronavirus depends on which strata you belong to and the hardest hit are the precariat. As governments introduced programs to limit unemployment or subsidize wages, the precarious workers could not benefit from the subsidy schemes (Alderman, 2020). The working poor $^{4}$ cannot work from home and either have lost their jobs or experienced loss of income, as lockdowns reduced their daily or hourly wages. The pandemic has shown that those at the lower strata of the social ladder are more likely to catch the disease or die because of it. Studies have long established the impact of socio-economic status inequalities and differences on health and mortality and exposure to different sorts of physical and health risks (Elo, 2009: 554). Heart disease mortality, asthma, and diabetes are more prevalent among the poor, which makes them more vulnerable. They are poorly nourished and have weaker immune systems. Therefore, it is not the virus but inequality that kills and the "pandemic-inequality" loop threatens to spread the disease and widen the gap between the rich and the poor (Fisher and Bubola, 2020).

Among the worst affected by the pandemic are the migrants. Many migrants have lost their jobs, as they did during and after the 2008 financial crisis (Knoll and Bisong, 2020). Many migrant workers employed in the worst-hit sectors by the pandemic triggered-economic downturn such as hospitality, domestic and care work, and agro-food industry lost their jobs, did have no or limited access to social protection or unemployment benefits and were forced into informality. Even if they carry out the "essential jobs" as the health crisis has revealed and are more exposed to health risks, they experienced wage cuts and deterioration of working conditions. The negative economic impact of the health crisis was

${ }^{4}$ The term "working poor" refers to the "employed persons living in poverty" or below the poverty line. It reveals the fact that earning an income does not guarantee a way out of poverty. While it is possible to talk about some progress in alleviating working poverty, in certain parts of the world, such as in Africa one-third of the workforce live in extreme poverty according to ILO 2018 figures. Working poverty, when combined with informality, alongside income inadequacy reveals problems such as lack of social protection and job security (ILOSTAT, 2019). 
much more profound on the workforce in the informal sector, particularly on the irregular migrant workers. Many female migrants working in the health and care sectors that were directly exposed to the risk of catching COVID-19 are irregular migrants. Some of the irregular migrants who did not lose their jobs continued to work without access to health care as they could not afford it or due to language barriers they were not well informed. Fearing deportation many also did not approach the authorities, while many others continued to work while sick in order not to lose their jobs. Loss of jobs or income also meant a significant decline in remittances sent to families in the countries of origin and limited the access of families dependent on remittances to food, health care, medicine, and other vital necessities (ILO, 2020).

Just before the outbreak of the pandemic, the Syrian refugee crisis was the issue dominating the EU agenda, as Chancellor Merkel, President Macron, and President Erdoğan were discussing the future of the Turkish-EU refugee deal and irregular migrants and refugees at the Turkish-Greek border. As COVID-19 moved on top of the agenda in all European countries, it shifted the attention away from the migration issue. Many member states decided to close their borders and imposed lockdowns and travel bans as a response to the pandemic. When Europe became the epicenter of the pandemic, the EU decided to close all Schengen area borders. Member states closed their borders to asylumseekers and some suspended asylum processing. Refugee resettlement has also been suspended due to travel restrictions, which extended the period that asylum-seekers would stay in overly crowded camps and be exposed to unhealthy conditions. Migrants, refugees, and asylum-seekers living in crowded camps or detention centers in and out of the EU, without access to health care, testing, treatment as well as clean water, sanitation or basic nutrition were exposed to higher risks of contagion. In certain EU countries, the provision of food and other necessities to migrants and refugees has been limited or stopped, while support services have been downscaled. Even among the most vulnerable many migrants, refugees and asylum-seekers were excluded from national emergency responses to COVID-19 (Amnesty International, 2020).

What is more worrisome however is not the spread of the disease among migrant or European populations. The newly introduced measures against COVID-19 and migration and the sense of suspicion and anxiety may take root and become hard to reverse (Knoll and Bisong, 2020). Migrants and refugees have to cope with a "secondary pandemic" due to hate speech, stigma, discrimination, and xenophobia. When seeking safety they become more vulnerable and exposed to violence (Amnesty International, 2020). The populists, seeking to use measures against the pandemic to push for further restriction of inflow of migrants and asylum-seekers into Europe started demanding harsher measures. Hungary closed its border transit camps for 
asylum-seekers, while Salvini, Italy's former Interior Minister, accused the Prime Minister of not closing the ports to humanitarian ships and allowing the spread of the disease in Italy. The Italian government, as part of a six-month state of emergency starting from 31 January, closed its ports declaring its ports to be unsafe due to COVID-19 and stated that the boats carrying migrants will not be allowed to dock until the emergency ends (Castelfranco, 2020). In the Netherlands, the populist radical right Forum for Democracy (FvD) and Party for Freedom (PVV) started to urge the government to close the borders, and adopt "lockdown" policies like that of Italy or Spain (Mudde, 2020).

The pandemic that instigated health and economic crises is now threatening democracy and the EU. Will liberal democracies and the EU survive the pandemic is an important question. In Hungary, Prime Minister Orban has used the coronavirus to extend his powers. He now has the power to suspend existing laws or issue new ones as long as the state of emergency declared to address coronavirus is in place (Zerofsky, 2020). This is unprecedented in the EU. Moreover, COVID-19 has tested the EU's solidarity, resolve, and adaptability. The EU's response was hampered by a lack of coordination, which is used by the anti-EU radical right to push for its agenda. Lack of support and solidarity was another major problem. When Italy, one of the worst-affected member states, sought the support of fellow member states, Austria did not allow the entry of Italian nationals into its territory; while Germany and France did not send the necessary medical goods such as masks to Italy when Italy needed them the most (Dayant, 2020). Germany and the Netherlands were adamant against the Italian and Spanish demands for the introduction of Eurobonds as a show of solidarity (Rachman, 2020). After long debates and negotiations, the EU leaders agreed on a $€ 750$ pandemic recovery fund to be delivered to member states as loans (European Council, 2020). The EU was caught unprepared for the health crisis and its economic implications. Its failure to immediately respond is likely to boost Euroscepticism in Southern Europe, which could easily be manipulated by the populists.

However, the pandemic poses certain challenges to the populist. While the populists could blame the corrupt elite for the 2008 financial crisis, they cannot do so for COVID-19. Even if they try hard to link COVID-19 with migrants or refugees, the disease can transgress borders and infect everyone regardless of one's status or identity. Moreover, mainstream political parties started to regain the trust and support of the people as competent actors to deal with the pandemic. This does not mean however that the pandemic would benefit the liberal democracies. The populists seek to adjust to the drastic changes due to the pandemic and we may see the emergence of "more nationalist and overtly authoritarian" populist actors and movements. One thing they would capitalize on would be growing anti-EU sentiment in European societies. Italy is a case in 
point. According to a recent poll, $67 \%$ of the Italians think that EU membership is disadvantageous for Italy (Kendall-Taylor and Nietsche, 2020). While Salvini and the League are losing public support, Brothers of Italy, a radical right party, has surged in support (Kendall-Taylor and Nietsche, 2020). At this point, it is hard to assess the impact of the pandemic, as there is not a single "rightwing populist response" to the pandemic. Some populist will use the developments to their benefit, while some would fail to do so and lose support (Mudde, 2020).

How the politics, democracies, and the populists in Europe would be affected is very important for the future of the EU and progressive politics. With the health crisis, the hitherto unquestioned neoliberal rationale is now challenged and as the pandemic and growing inequality disproportionately affect certain groups, the questioning will open up more room for alternative answers. Populism might reinvent itself or experience a sudden decline. Alternatively, the EU might survive the pandemic and reinvigorate solidarity among the member states, which might lead to the construction of a "postpopulist era" in Europe (Kendall-Taylor and Nietsche, 2020). New thinking and new expectations of the people would transform Europe. The progressives' ability to adapt to change and create a new narrative (Skryzpek, 2020) will define the future of progressive politics in European and global politics.

\section{In Lieu of Conclusion: Possible Responses by the Left}

Today, we are at a point where there is the need to leave behind neoliberalism and failed responses to it hitherto adopted by the Left (Coates, 2018: 3158). It is possible to talk about the crisis of social democracy, however, this does not also mean a crisis of "social democratic ideals" (Mudde, 2019). Therefore, the progressive left has to develop a future-oriented discourse based on openness, pluralism, and collaboration (Dayant, 2020). The Left has to build alliances or a coalition based on participatory democracy with the "core goals of social justice, redistribution, solidarity and environmental sustainability" (Bailey, 2018: 5321). This might carry the progressives to power, and if they win the elections, it might help them pursue policies sticking to the core values that carried them to power.

However, rather than constraining itself to electoral politics, it is more important for the Left to establish a new movement. In a world irreversibly transformed by the pandemic, which revealed the fact that we are living in an extremely unequal world, how to deal with growing inequality is the key question and it is the question around which progressive politics should mobilize. Bourdieu in his "Acts of Resistance" argued that neoliberal globalization rolled back the achievements of the labour movement and sought to challenge the role of the state "as the guardian of the public interest" (1998: 2-3). He criticized the welfare retrenchment, which was presented as an urgent 
requirement, and called for "new internationalism" to organize against the neoliberal globalization through the "mobilization of the peoples" and "action on and through the nation-states" to constitute a "transnational social state" in Europe (Bourdieu, 1998: 64-66.). Today, we see the dire consequences of cuts in government spending in healthcare in the last decades and certain demands seeking to empower the people such as public health care, policies addressing socio-economic inequality or climate change, increasing the minimum wage or providing affordable housing for low-income households that were brushed off as "unreasonable" in neoliberal times now seem very reasonable and essential (Jones, 2020). It is vital for social democracy, particularly in the post-COVID19 world, to stick to its values and seek to make these values dominate the agenda.

Today, the Left has a historic opportunity to challenge the neoliberal assumptions about the market head-on. The current global economic order is working to the detriment of the health of working classes and the Left has to develop "just responses". By putting human rights first, the Left may also develop responses to reactionary and xenophobic radical right rhetoric or efforts to undermine democracy. The pandemic has shattered the "neoliberal dogma" that there are no alternatives to existing economic order and has shown that policies to address economic injustice and climate change could be implemented when necessary. Policies, once considered to be way too ambitious, now seem to be the right responses to cope with the crisis (The Transnational Institue, 2020). The markets and economic processes are socially constructed. There is nothing instinctive or natural about the emergence of the markets. Therefore, the market is not a natural phenomenon, it is socially constructed and the division of economic and social spheres, as defended by the neoliberal ideology, is artificial (Golubovic and Golubovic, 2012: 9). There is a need for regulation (rulemaking and rule enforcement) for universal health care and protection of the environment.

A fair, equal, and democratic Europe is possible if an inclusive social movement is constructed. For this to occur, the progressives have to win back the trust of the electorate by gaining credibility they have lost by embracing neoliberal reforms (Skrzypek, 2015: 10) and create a non-neoliberal common sense based on egalitarianism and solidarity. Social democrats must come out of their defensive position and be more assertive of their ideals (Skrzypek, 2015: 4; Coates, 2018: 3163-3164). More importantly, rather than presenting itself as an alternative, progressive politics should claim to be the main agent of social transformation (Skrzypek, 2015: 5). 
Establishing a new movement would require the trade unions to be more inclusive and integrate migrants, women, and insecure workers into their fold and challenge transnational capital by a European social movement (Mathers, 2007: 163). Rather than retreating to nationalism, the Left should seek to organize transnationally at the European scale and develop a transnational strategy and alternative models of globalization. Therefore, the social movement against neoliberalism has to organize like neoliberal governance along trans- or post-national lines (Worth, 2018: 5108) while developing mechanisms for the empowerment of members and participatory democracy (Skrzypek, 2015: 5).

The immigration issue is one of the key issues for the Left. Rather than adopting the radical right discourse on immigration, the Left should seek to desecuritize migration (Bloomfield, 2020: 95; Boros, 2016). The pandemicrelated health crisis revealed the important contributions that migrants make to our lives by working as frontline workers in health and care sectors, as well as workers in agriculture, food processing, transportation, factories, supermarkets or cargo companies. Their work is essential and indispensable and the survival of the economy and people largely depend on their work. The pandemic, therefore, leads to the questioning of anti-immigrant rhetoric and this questioning may allow the Left to create a new narrative on migration in postcoronavirus Europe. If the Left succeeds in setting the agenda of European politics on Social Europe to alleviate inequality, to provide public services, and to seek higher wages for the working classes, this will also benefit the migrants and refugees (Boros, 2016). During the pandemic, migrants have faced significant challenges in accessing health care or government support programs. The health crisis has revealed the significance of reprioritizing public spending to construct sustainable, socially and gender-responsive, affordable social protection that will also cover (regular and irregular) migrant workers (ILO, 2020). The progressive politics need to push for such an agenda.

Even if we seek to compare the COVID-19 crisis with other previous crises to anticipate what to expect, it is not like any of them. As Joschka Fisher argues, its implications are likely to be "more dangerous and extensive" than those of the 2008 global economic recession (Fischer, 2020). Many scenarios are envisaged about what the future holds. Progressive politics should focus on offering or creating positive scenarios that will enhance solidarity. This is a pandemic affecting all humanity and it seems that it is not going to be the last crisis. Therefore, progressive politics has to proactively engage in building up solidarity and formulate responses that would allow people struggling to survive in these hard times to feel that they are not alone. The pandemic presents an opportunity for the progressive politics to reconstruct itself to have a key role in the post-coronavirus world and push for a forward-looking and more inclusive strategy focusing on health, well-being, and security of the people with new vigour. 


\section{References:}

Alderman, L. (2020) In Europe, Millions of Jobless Are Falling Through the Cracks, The New York Times, 13 August, <https:/www.nytimes.com/ 2020/08/13/business/europe-precarious-workers.html>, (24 August 2020).

Amnesty International (2020) "Amnesty International Public Statement: Refugees and Migrants Forgotten in COVID-19 Crisis Response", ACT30/2319/2020, 14 May, <https://reliefweb.int/sites/reliefweb.int/files/ resources/ACT3023192020ENGLISH.pdf>, (26 August 2020).

Bailey, D. J. (2018) "Chapter 47. Neoliberalism and the Left: Before and After the Crisis", in D. Cahill, M. Cooper, M. Konings, and D. Primrose (ed.), The SAGE Handbook of Neoliberalism, (Los Angeles: Sage), pp. 5273-5382.

Benedetto, G., Hix, S. and Mastrorocco, N. (2019) "The Rise and Fall of Social Democracy, 1918-2017", 1 July, Trinity Economics Papers, Trinity College Dublin, Department of Economics, <http://personal.lse.ac.uk/hix/Working Papers/BHM_Rise_and_Fall_of_SD.pdf $>$, (24 August 2020).

Berezin, M. (2011) Neoliberal Zamanlarda Liberal Olmayan Politikalar: Yeni Avrupa'da Kültür, Güvenlik ve Populizm, (çev. Enis Köksaldı), (İstanbul: İstanbul Bilgi Üniversitesi).

Bloomfield, J. (2020) "Progressive Politics in a Changing World: Challenging the Fallacies of Blue Labour", The Political Quarterly, 91(1): 89-97.

Boros, T. (2016) "Populism and Migration: Challenges for the Left," Das Progressive Zentrum, 15 March, <https://www.progressives-zentrum.org /populism-and-migration-challenges-for-the-left/?lang=en>, $(24$ January 2020).

Bourdieu, P. (1998) Acts of Resistance: Against the Tyranny of the Market, (translated by Richard Nice), (New York: The New Press).

Castelfranco, S. (2020) "Italy Closes Ports to Charity Migrant Ship over Covid19 Infection Fears," Rfi, 8 April, <http://www.rfi.fr/en/europe/20200408italy-closes-ports-to-charity-migrant-ship-over-covid-19-infection-fearsmediterranean-coronavirus>, (13 April 2020).

Chaplain, C. (2019) "What is Blue Labour, the Controversial 'Culturally Conservative' Group Calling for Support to Shape the Future of the Party?" iNews, 16 December, <https://inews.co.uk/news/politics/blue-labour-whattwitter-party-group-culturally-conservative-policies-explained-1342190>, (30 December 2019).

Coates, D. (2018) "Chapter 28. Progressive Politics Under Neoliberalism", in D. Cahill, M. Cooper, M. Konings, and D. Primrose (ed.), The SAGE Handbook of Neoliberalism, (Los Angeles: Sage) pp. 3097-3180. 
Dayant, A. (2020) "Covid-19 and Migration: Europe Must Resist a Populist Pill," Lowly Institute, 23 March, <https://www.lowyinstitute.org/theinterpreter/covid-19-and-migration-europe-must-resist-populist-pill>, April 2020).

Elo, I. T. (2009) "Social Class Differentials in Health and Mortality: Patterns and Explanations in Comparative Perspective", Annual Review of Sociology, 35: 553-572.

European Commission (2010) "Commission Staff Working Document: Lisbon Strategy Evaluation Document," 2 February, SEC(2010) 114 Final, $<$ https://ec.europa.eu/archives/growthandjobs_2009/pdf/lisbon_strategy_eva luation_en.pdf $>$, (23 August 2020).

European Council, Council of the European Union (2020) "COVID-19: The EU's Response to the Economic Fallout", <https://www.consilium. europa.eu/en/policies/coronavirus/covid-19-economy/>, (26 August 2020).

Fisher, M. and Bubola, E. (2020) "As Coronavirus Deepens Inequality, Inequality Worsens Its Spread," The New York Times, 15 March, <https:// www.nytimes.com/2020/03/15/world/europe/coronavirus-inequality.html>, (12 April 2020).

Fischer, J. (2020) "The Politics of the Pandemic," Project Syndicate, 1 April, $<$ https://www.project-syndicate.org/commentary/european-union-covid19politics-by-joschka-fischer-2020-04>, (11 April 2020).

Golubovic, N. and Golubovic, S. (2012) "Embedded" Neoliberalism, FACTA UNIVERSITATIS, Economics and Organization, 9(1): 1-13.

Hacker, B. (2014) "Social Europe as a Field of Conflict: Four Challenges and Opportunities to Shape the European Social Model", Friedrich Ebert Stiftung, <https://library.fes.de/pdf-files/id/ipa/10985.pdf>, (24 August 2020).

Human Rights Watch (2020) "Greece: Violence Against Asylum Seekers at Border," 17 March, <https://www.hrw.org/news/2020/03/17/greeceviolence-against-asylum-seekers-border>, (12 April 2020).

Hürtgen, S. (2020) "Precarization of Work and Employment in the Light of Competitive Europeanization and the Fragmented and Flexible Regime of European Production", Capital \& Class, 1-21, published online ahead of print, 11 February 2020, DOI: 10.1177/0309816819900123.

ILO (2020) "Social Protection Spotlight. Social Protection for Migrant Workers: A Necessary Response to the Covid-19 Crisis", ILO Brief, 23 June, <https://www.ilo.org/wcmsp5/groups/public/---ed_protect/---soc_sec/ documents/publication/wcms_748979.pdf $>$, (25 August 2020).

ILOSTAT (2019) "The Working Poor or How a Job is No Guarantee of Decent Living Conditions," April, No. 6, <https://www.ilo.org/wcmsp5/ 
groups/public/---dgreports/---stat/documents/publication/wcms_696387. pdf>, (23 August 2020).

IMF (2020) "The Great Lockdown: Worst Economic Downturn Since the Great Depression", Press Release No. 20/98, 23 March, $<$ https://www.imf.org/en/News/Articles/2020/03/23/pr2098-imf-managingdirector-statement-following-a-g20-ministerial-call-on-the-coronavirusemergency>, (25 August 2020).

Jones, V. (2020) "Sanders Exits as Pandemic Redeems His Core Ideas," CNN, 8 April. <https://edition.cnn.com/2020/04/08/opinions/bernie-sanders-exitspandemic-redeems-ideas-jones/index.html >, (24 August 2020).

Kallis, A. (2014) "The Radical Right in Contemporary Europe", SETA Analysis, No.13. <http://file.setav.org/Files/Pdf/20150102163845_the-radical-right-incontemporary-europe-pdf.pdf>, (20 April 2020).

Kendall-Taylor, A. and Nietsche, C. (2020) "The Coronavirus Is Exposing Populists' Hollow Politics", Foreign Policy, 16 April, $<$ https://foreignpolicy.com/2020/04/16/coronavirus-populism-extremismeurope-league-italy/?fbclid=IwAR1o_BurN1I_DG8Rvg7DNMiOkofIBzA_ JOejfWWSGcB7TReBCyHUVleys3o>, (18 April 2020).

Knoll, A. and Bisong, A. (2020) "Migration, Mobility and COVID-19 - A Tale of Many Tales," ECPDM, 30 March, <https://ecdpm.org/talkingpoints/migration-mobility-covid-19-tale-of-many-tales/>, (13 April 2020).

Levenson, E. (2020) "Why New York is the Epicenter of the American Coronavirus Outbreak," 26 March, <https:/edition.cnn.com/2020/ 03/26/us/new-york-coronavirus-explainer/index.html>, (12 April 2020).

Mathers, A. (2007) Struggling for a Social Europe: Neoliberal Globalization and the Birth of a European Social Movement (Aldershot: Ashgate).

Mendizabal, N. C. (2014) "Crisis Management, Re-Centralization and the Politics of Austerity in Spain”, International Journal of Iberian Studies, 27(1): 3-20.

Mudde, C. (2020) "Will the Coronavirus 'Kill Populism'? Don't Count On It," The Guardian, 27 March, <https://www.theguardian.com/commentisfree/ 2020/mar/27/coronavirus-populism-trump-politics-response>, (29 March 2020).

Mudde, C. (2019) "Why Copying the Left Isn't Going to Save the Left," The Guardian, 14 May, <https:/www.theguardian.com/news/2019/may/14/whycopying-the-populist-right-isnt-going-to-save-the-left>, (24 January 2020).

Mudde, C. (2007) Populist Radical Rigth Partiesin Europe, (Cambridge: Cambridge University Press). 
Niven, A. (2019) "The Labour Party's Spectacular Defeat Had Been Coming for Decades," The New York Times, 20 December, <https://www.nytimes.com/2019/12/20/opinion/uk-election-labour.html>, (24 January 2020).

Nugent, W. (2010) Progressivism: A Very Short Introduction, (Oxford: Oxford University Press).

Rachman, G. (2020) "Eurobonds Are not the Answer," Financial Times, 6 April, <https://www.ft.com/content/b809685c-77de-11ea-af44-daa3def9ae 03>, (20 April 2020).

Robbins, P. (2015) "The Greek Debt Crisis: The Need for "Heroic" Economic Policy Reforms in the European Economic and Monetary Union", Indiana Journal of Global Legal Studies, Article 10, 22(1): 175-199.

Robinson, E. (2017) The Language of Progressive Politics in Modern Britain, (London: Palgrave Macmillan).

Rowson, J. (2015) "What is a 'Progressive'?" 11 June, <https://www. opendemocracy.net/en/opendemocracyuk/what-is-progressive/>, (22 August 2020).

Ryner, M. (2018) "Chapter 19. Neoliberalisation of European Social Democracy: Transmissions and Dispositions", in D. Cahill, M. Cooper, M. Konings, and D. Primrose (ed.), The SAGE Handbook of Neoliberalism, (Los Angeles: Sage), pp. 2071-2191.

Scharpf. F. W. (1995) "Negative and Positive Integration in the Political Economy of European Welfare States", Jean Monnet Chair Papers 28, (Florence: The Robert Schuman Centre at the European University Institute).

Schierup, C.-U., Hansen, P. and Castles, S. (2006) Migration, Citizenship, and the European Welfare State: A European Dilemma, (Oxford: Oxford University Press).

Silvia, S. J. (1991) "The Social Charter of the European Community: A Defeat for European Labor," Industrial and Labor Relations Review, 44(4): 626643.

Sirota, D. (2011) "What's the Difference Between a Liberal and a Progressive?" The Huffington Post, 25 May, <https://www. huffpost.com/entry/whats-the-difference-betw_b_9140>, (24 August 2020).

Skryzpek, A. (2020) "Solidaristic, Social and Sensible - Reflections on Progressivism for Today and When Tomorrow Comes," Social Europe, 17 April, <https://www.socialeurope.eu/solidaristic-social-and-sensible-reflect ions-on-progressivism-for-today-and-when-tomorrow-comes $>, \quad(20$ April 2020). 
Skrzypek, A. (2015) "Progressive Politics in Fragmented Times: 10 Core Guidelines," FEPS Policy Brief, September.

Tidey, A. (31 July 2020) "Coronavirus: Euro Area Economy Shrinks by 12.1\%Biggest Drop on Record," Euronews, <https://www.euronews.com/ 2020/07/31/coronavirus-euro-area-economy-shrinks-by-12-1-biggest-dropon-record $>$, (22 August 2020).

Tooze, A. (2020) "The Normal Economy Is Never Coming Back," Foreign Policy, 9 April, <https://foreignpolicy.com/2020/04/09/unemploymentcoronavirus-pandemic-normal-economy-is-never-coming-back/>, (11 April 2020).

The Transnational Institute, (2020) "Coronavirus: The Need for a Progressive Internationalist Response,” 26 March, <https://www.tni.org/en/article/ coronavirus-the-need-for-a-progressive-internationalist-response $>$, (8 April 2020).

U.S. Bureau of Labor Statistics, "The Employment Situation - July 2020", News Release USDL-20-1503, <https://www.bls.gov/news.release/pdf/ empsit.pdf>, (24 August 2020).

van Apeldoorn, B. (2009) "The Contradictions of 'Embedded Neoliberalism' and Europe's Multi-level Legitimacy Crisis: The European Project and its Limits", in B. van Apeldoorn, J. Drahokoupil and L. Horn (eds.), Contradictions and Limits of Neoliberal European Governance: From Lisbon to Lisbon (London: Palgrave Macmillan), pp.21-43.

Wheeler, B. (2010) "So What Exactly is 'Progressive' in Politics?" BBC, 26 November, <https://www.bbc.com/news/uk-politics-11785483>, January 2020).

World Health Organization (2020) "WHO Announces COVID-19 Outbreak a Pandemic," 12 March, <http://www.euro.who.int/en/health-topics/healthemergencies/coronavirus-covid-19/news/news/2020/3/who-announcescovid-19-outbreak-a-pandemic>, (12 April 2020).

Worth, O. (2018) "Chapter 45. Resistance to Neoliberalism Before and Since the Global Financial Crisis," in D. Cahill, M. Cooper, M. Konings, and D. Primrose (ed.), The SAGE Handbook of Neoliberalism, (Los Angeles: Sage), pp. 5090-5177.

Zerofsky, E. (2020) "How Viktor Orban Used the Coronavirus to Seize More Power," The New York Times, 9 April, <https://www.newyorker. $\mathrm{com} /$ news/letter-from-europe/how-viktor-orban-used-the-coronavirus-toseize-more-power>, (12 April 2020). 